\title{
Adapting The Tempest
}

\author{
By Antonio Sanna \\ Spring 2015 Issue of KINEMA
}

\section{ADAPTING THE TEMPEST: JULIE TAYMOR'S REVELS}

Adaptations and appropriations of Shakespeare's plays demonstrate the unending life of a series of canonical texts that still invite numerous forms of interpretation. Simultaneously, they also offer a tool for the (re)interpretation of the English playwright's works. This is definitely the case of Julie Taymor's recent film The Tempest (2010), which partially alters the structure of Shakespeare's last solo play, but also actively engages with the academic debates on the work's thematic concerns. Nevertheless, Taymor's film could be seen as faithful to the original source and as fully realizing on the screen its fantastic elements, especially through the use of the special effects.

Taymor's The Tempest utilizes the original heightened language of the seventeenth century - which certainly gratifies those spectators that enjoy what Stephen Greenblatt has defined as Shakespeare's "infinite delight in language"(1) - and maintains the main dialogues of the original text, although many verses have been cut out of the film's script. Compared to the previous adaptations of this play, the textual cuts are however minimal. Derek Jarman's The Tempest (1979) and Peter Greenaway's Prospero's Books (1991) in fact notably alter the structure of the original work. The former anticipates the presentation of Caliban, delays Prospero's tale of the background story and repeatedly overturns the order of the characters' lines, but also adds some scenes such as a dialogue between Miranda and Ariel (who never speak to each other in the original play). In the case of Prospero's Books, the presentation of many images as fragmented, the use of digital image manipulation and the frequent insertion of the frame-within-the-frame - which, according to Mariacristina Cavecchi, reproduces Shakespeare's device of the play-within-the-play (qtd. in Hopkins 164) - actually deconstruct the original text, but also permit the illustration in detail of everything that is mentioned in Prospero's narration. Common to both films is the depiction of many scenes and characters (such as Sycorax and Prospero's wife) that are only mentioned in the original text as part of the protagonist's background story or of the island's past.

The major difference between Taymor's work and Shakespeare's play (and the previous cinematic versions of it) is due to the substitution of the male protagonist Prospero with the female Prospera, excellently interpreted by Helen Mirren. This choice determined an a priori rearrangement of the original text, especially the personal pronouns and noble titles referring to Prospero, but also the words referring to his attire. The term "sir" thus becomes "ma'am" or "dame", "father" is translated as "mother" and "Duke" is corrected as "Duchess". In the fifth act of the play, Ariel fetches his master's elegant clothes so that Prospero can introduce himself to Alonso, Gonzalo, Sebastian and Antonio as he was (when he governed) Milan, whereas in Taymor's film "the hat and rapier" (V, I, 84) are substituted by "the skirt and bodice" (designed by Oscar-nominated Sandy Powell).

Nevertheless, although the alteration of the protagonist's sex should imply a fundamental change in the perspective of the narrative, the film could not be generally defined as a feminist retelling of Shakespeare's work. Certainly, the gender politics of the story have been inverted because a woman is assigned a position of power over a group of men. However, the change of the magician's sex influences principally the facts constituting the background story narrated to Miranda in the first act of the play. The plot ordained by Prospera's brother Antonio (Chris Cooper) is to be read as a prevarication of the male over the female sex in the 2010 film. This argument is specifically corroborated by the director's addition of a few verses to the text of the English playwright: the "closeness and the bettering of my mind" (I, ii, 90) resulting from the magician's rapt immersion in the secret study of magic - which cause Prospero's neglect of the dukedom and offer his brother the opportunity to usurp the throne - are instead seen as leading to a charge of witchcraft in Taymor's work. Indeed, when revealing the story of their banishment to her daughter (Felicity Jones), Prospera blames Antonio for accusing her of being "A practitioner of the black arts. A demon, not a woman, nay, a witch! And he full knowing that others of my sex have burned for no less".

Antonio's betrayal of Prospera is presented as a misogynist action therefore, motivated by personal greed but 
also "legitimized" by dread of a woman's intelligence and empowerment and by fear of transgression of the accepted gender boundaries, as the film director herself evidences when affirming that "she had her whole life taken away from her because she was a woman" (qtd. in Breznican). Prospera's revenge against her male rivals could then be interpreted as a way to prevent the same thing from happening to her daughter, which she obtains by ensuring Miranda's happy marriage with the King's son Ferdinand and the removal of Antonio from institutional power.

Another conspicuous change to the original text is the dislocation of the utopian narration by Councillor Gonzalo (Tom Conti). Such a discourse - taken from the second act of the play and partly based on and inspired by Montaigne's pamphlet "On Cannibals" (O'Toole) - has been transferred after the second encounter between Miranda and Ferdinand (Reeve Carvey), probably to lighten the tone of the scene or merely to divide a long scene into two parts. Nevertheless, this expedient offers the director the opportunity to change the original text's unique setting of this scene into two different locations: the first part of the dialogue occurs in an open savannah-like space with arid soil and bare trees - visually representing the void perceived by Alonso (David Strathairn) for the alleged loss of his son during the tempest - whereas the second part is set in the middle of a thick wood. The latter setting perfectly exemplifies the intricacy of the plot proposed by Antonio to kill the asleep King of Naples and Gonzalo. As the murderous thoughts are slowly poured in Sebastian's ears - in a scene which evokes the "temptations" of Lady Macbeth, Cassius and Iago - so the two characters walk among the tree trunks, almost reproducing the creeping movements of snakes. ${ }^{(1)}$

A cinematic version of Shakespeare's work can fully realize the potentiality of the images described by the actors and merely imagined by the play's readers/spectators. As Lisa Hopkins has noted, because of its few props and no scenery the Shakespearean stage instead "inevitably depended heavily on the characters' verbal descriptions to inform the audience of where they were and what it looked like" (16). Taymor's film clearly emphasizes the concept of an island setting. Indeed, contrary to Jarman's and Greenaway's setting of the story respectively in the interiors of a mansion (Stoneleigh Abbey in Warwickshire) and inside the reproductions of Renaissance-like halls and baths, the 2010 cinematic version of the story has been mainly filmed in the Hawaiian island of Lanai, which offered a series of natural landscapes that allowed the neat differentiation of all the locations from each other.

The scenery is indubitably very varied, from the black lava field where the dark harpies appear (a proper setting for a horror or a science-fiction film as well) to the red volcanic hills where Trinculo and Stefano (the very talented Russell Brand and Alfred Molina, both of them wearing very coloured costumes) encounter Caliban, from the high cliffs (on which Prospera appears with a blue cloak recalling the shape of a volcano and thus perfectly exemplifying the eruption of the rage she was forced to contain during the twelve years of banishment) to the luxuriant and swampy pool near Prospero's cell. Apart from gratifying the spectators' visual pleasure for their fascinating beauty, all of these settings have been therefore coupled with the actors' costumes and offer an excellent variety of colours that are simultaneously expressive of the atmosphere and mood of each sequence.

However, the island portrayed in the film is not structured like a classic labyrinth, a detail which, according to Flaminia Nicora (276), is clearly indicated in the original text, in which the characters find no intersections and alternative routes but are drawn by Prospero to the centre of the maze that is the sorcerer's cave. Such an argument is validated by the text's recurrent definition of the island as a maze. ${ }^{(2)}$ According to Nicora, the cave thus figures as a sort of pivotal centre around which the characters revolve, in a sort of spiral whose centre is Prospero, "acting at once as a guiding principle that leads his characters and as a nemesis, a Minotaur they all must face; an abyss from which, eventually, they will emerge to new light" (279) after the confrontation with their selves and their guilty consciences. In Taymor's film, the line reporting Alonso's description of the island "as strange a maze as e'er man trod" (V, I, 243) has been omitted. There are no verbal indications about the shape of the island or any extreme long shots of it: viewers can only watch the single areas where the characters' actions occur but the distance between them can never be established.

Another major alteration to the Shakespearean text regards the masque-within-the-play depicting the apparitions of Ceres, Iris and Juno (IV, I, 60-138), a scene that reproduces that "pre-operatic" genre that became popular at the beginning of the seventeenth century, genre in which "words combined with dance, music, pas- 
toral and mythological costumes" (Serpieri xliii). The masque is introduced by the declamation "No tongue! All eyes! Be silent!", which intends to capture Ferdinand' and Miranda's (and the readers'spectators') whole attention. In the original play the three mythological figures of Ancient Greece are evoked to celebrate the romantic union of the young couple, to promise them fertility and richness. This has been realized almost to the letter by Greenaway, in whose film the masque is a procession of many coloured figures who offer their gifts to Ferdinand and Miranda, either naked or embellished by gorgeous costumes recalling Renaissance paintings. In this sequence from Prospero's Books Ceres, Iris and Juno actually appear, singing almost all of the original text's lines and performing in front of the couple.

However, in Taymor's version, only the purpose to show "some vanity of [Prospero's] Art" (IV, I, 41) seems to be fulfilled: star maps are drawn, various geometrical shapes and the symbols of the zodiac signs are continually superimposed over real stars and nebulae in a sort of representation of a cartographer's reverie. Alternating his figure to a white dove and an orchid, a diaphanous and bare-breasted Ariel (Ben Whislaw) then appears in the middle of the frame and is symmetrically duplicated or exponentially replicated: contrary to the original play (in which Ariel only evokes the other spirits) here he participates to the magic vision as himself.

Contrary to the theatrical work and to Greenaway's adaptation of it, in which the scene requires some minutes to be recited in its entirety, in Taymor's film the masque is very short and readily interrupted by Prospera's recollection of Caliban's murderous plan against her person. With the exception of very few verses (such as Ferdinand's first address to Miranda "Most sure the goddess on whom these airs attends", an echo of Aeneas' words in the first book of the Aeneid) and the scene of the harpies, the film's script thus mainly removes the echoes of Virgil and many references to Classical mythology. Taymor's masque becomes a vain demonstration of Prospero's power as well as pure spectacle and music, especially because it is preceded by Ferdinand's song, an addition to the script which has been actually borrowed from the Bard's comedy The Twelfth Night. The delicate and romantic song for Miranda (whose intimacy with Ferdinand is now emphasized by the two-shots constantly framing them together) is not only chronologically and musically related to the magic revels created by Prospera, but also visually made one with it. Indeed, the whole scene has been filmed through a blue filter, which heightens the impression of the twilight time of dreams, but also erodes the distinction between the vision produced by magic and the reality of the two young spectators.

Taymor's representation of Prospera's revels is exemplary of Alden T. Vaughan' and Virginia Mason Vaughan's argument that "as perhaps the dramatist's most spectacular play, The Tempest is ripe for film's fluidity of visual image" (qtd. in Hopkins 151). This is particularly evident in the realization of the character of Ariel on the screen, which definitely bypasses all the technical difficulties of the (Elizabethan) stage by means of the digital special effects as much as it serves as a real advert of what the latter can do. Ariel could be differently imagined by The Tempest's readers, who must nonetheless necessarily assume the physical presence of the actor/actress on the stage when attempting to depict in their minds the realization of the play in a theatre. Similarly, during the representation of the play in a theatrical space, viewers have to imagine what is invoked by a character's words to picture in their minds the events that could not be represented on the stage or that need to be summarized, as is the case also in other Shakespearean works such as Henry $V$ and Pericles, Prince of Tyre which, respectively through the chorus and the figure of Gower, repeatedly encourage the spectators to use their "imaginary forces" (Henry V, Prologue, 18).

On the contrary, in the cinematic medium the conceptual images of the reader (controlled by the playwright's directing and selected words) assume a final and definite visual form and are liberated from the confines of the acting space of the theatre. In Taymor's film, the spectator directly witnesses the unnatural movements of Ariel, who is ethereally pale and appears to be made of air - as the play specifies when Prospero addresses him by saying "thou, which art but air" (V, I, 21) - but also of many elemental forces of nature, the very forces that the spirit can manipulate at his command. Ariel jumps out of the water as a geyser, his contour assumes the shape of flames when he sets the vessel on fire, he speedily changes his size and assumes the form of the trees' trunks.

In the 2010 film he definitely appears to be non-material, contrary to Jarman's and Greenaway's very corporeal representations of the character. In the 1979 The Tempest a fully-dressed Ariel (interpreted by Karl Johnson) alternates his (expressionless) voice-over interventions and barely-tuned songs to his presence 


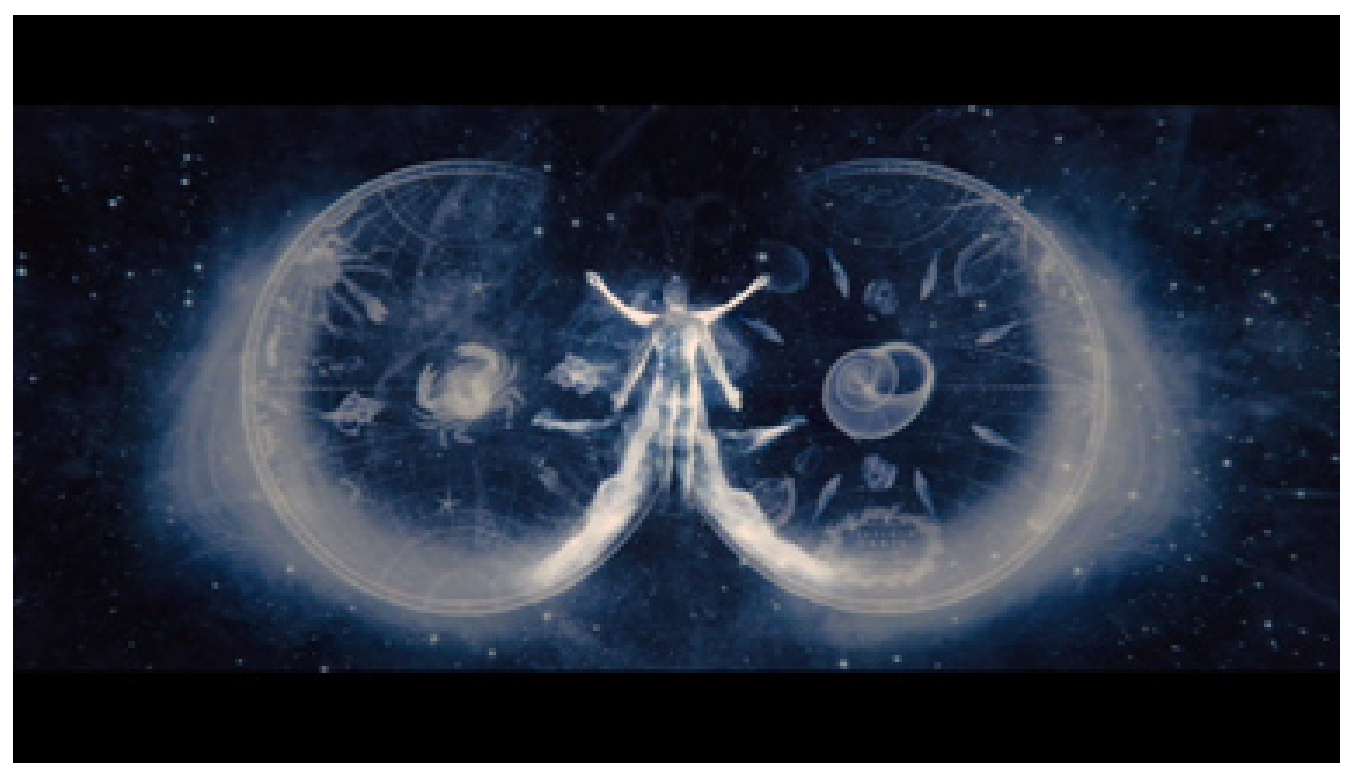

Figure 1: Image 1: Prospera's magic vision

on the screen, a presence that certainly has or inspires no magic. In Prospero's Books the character is instead interpreted by four different actors, all wearing blond, curly and Cherub-like wigs. According to Sara Martin (qtd. in Hopkins 172), Greenaway's Ariels represent the four elements. However, we could say that they are corporeal incarnations of the spirit, as their physical contact and interaction with many characters demonstrate (as when they strip Prospero's adversaries of their hats and masks, and kiss them to instill torpor in them). Moreover, they do not exhibit any supernatural powers such as flying; instead, they merely hang loose and swing from the vaults by means of a seesaw and elastic cords.

In Taymor's film Ariel's most spectacular actions occur instead in the many "asides" between him and Prospera, when he ghostly appears on the sorceress' side, hovering continually around her with jerking movements. Considering that, as the documentary "Raising The Tempest" (2010) shows, the actor was not even present on the Hawaiian island during the filming but his figure was added to the frames in the film's post-production, Ariel's apparitions on the screen are all the more spectacular as the result of the modern "magic" produced by contemporary special effects.

The same is true for the exit of the character from the stage: in a theatrical adaptation of this work we would expect Ariel to walk off the stage, or perhaps to disappear through a trapdoor. In Taymor's version, Ariel completely ignores the law of gravity and twirls in the sky, spinning around himself and always leaving a white trail of smoke after him. He also sometimes appears as framed through a veil made of water, whose wavy movement creates the ambiguous impression of female breasts on his naked chest. In this respect, Taymor's film fully demonstrates the capacity to do better than the stage with the elements of magic in the play and can be faithful to the fantastic occurrences of the primary story by "concretizing" them.

Many other scenes of the film have been rendered all the more spectacular by means of modern special effects, such as the opening sequence of the tempest. With the exception of two long shots that frame the ship caught in the storm - representing respectively Miranda's and Prospera's points of view from the island - viewers are never shown the vessel in its entirety but only its main deck. However, the rolling of the ship and the water continually "assaulting" it through the rain and the waves are very realistic and convincing, especially when the windows of the cabin where the King and Ferdinand are praying are broken by the strength of the sea. In the Shakespearean text, the effects of the storm on the ship and its crew can be initially inferred by the fear of imminent death and the desperation verbally expressed by the mariners and the boatswain, but are subsequently completed by Miranda's description of the vessel being "Dash'd all to pieces" (I, ii, 8).

Apart from the screams of the boatswain, who is more preoccupied with losing his own life than with 
respecting the royal authorities on board, in the 2010 film fear of imminent of death is expressed also through the king's compassionate glance and caress to his son Ferdinand. This sequence is all the more realistic if we compare it to its equivalent in Prospero's Books, in which the tempest itself is represented by some of the sorcerer's books being wet by the rain and by the youngest Ariel urinating over a ship toy model floating in a pool. The actual vessel is never portrayed on the screen whereas its crew is briefly framed a couple of times, standing on the deck under the rain while posing in front of the camera, showing no agonized or frightened expressions.

Special effects are useful not only for the creation of non-human figures or the reproduction of events that could be hardly adaptable on a theatrical stage, but also for the support of a character's words and emotions and the intensification of a scene's atmosphere. An example could be the protagonist's soliloquy from the fifth act of the play (33-57) - part of which is a close translation of a speech of Medea in Ovid's Metamorphoses. In this sequence the excellent acting skills and talent of Mirren are sustained by the special effects creating the environmental turmoil that corresponds to the internal turmoil of the character. When Prospera raises the volume of her voice, many clouds completely hide the blue sky in the background, the wind strengthens and light gradually grows in its intensity whilst the incantation proceeds and the sun's eclipse disappears. In this moment, Prospera is revealed as what William Boelhower defines as an "atmoterrorist", "a clandestine magician-climatologist who, if we stop to think of it, has totally militarized the island's ecosystem"(3). Simultaneously, the camera circles around the character as if it were positioned in the very ring of fire she has created: the accelerating movement and kinetic energy around the sorceress definitely intensify the suspense and suggest the physical reaction of nature to the powers she possesses.

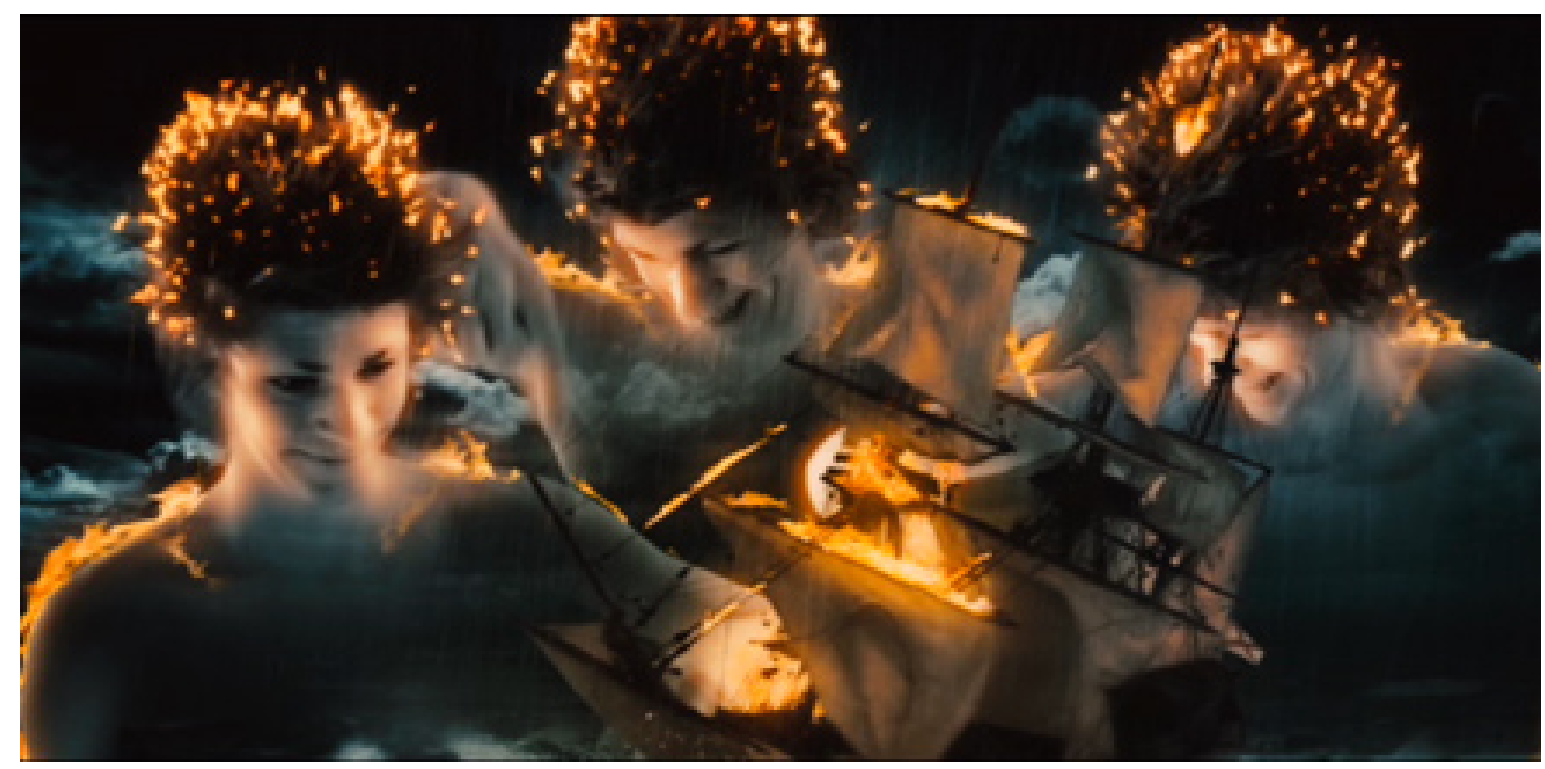

Figure 2: Image 2: Ariel's elemental transformation during the tempest

Such an accelerating movement and turmoil are absent in Jarman's representation of this soliloquy, which is characterized by a series of very static close-up frames of the main character (Heathcote Williams), who appears to be merely recalling his past while sitting on a chair and peering into a book of spells, but with no evident feelings about it, as the actor's flat recitation suggests. In Greenaway's film, some movement is created by the slow walk of Prospero (John Gielgud) towards the camera (that he never faces directly) and by the procession of actors and dancers surrounding and following him as well as by the alternation of such a frame with the close-ups of several books being abruptly closed. The protagonist's voice raises and becomes more and more emphatic as the recitation progresses but he then abruptly stops to inspect the four Ariels drawing a circle on a table. Rather than a renunciation of magic, Gielgud's performance suggests the evocation of the four spirits for the entrapment of his adversaries.

By contrast, in the 2010 version as soon as Prospera utters the words "my so potent art" the flames are 
extinguished, her glance and head are lowered to the ground, the sky becomes serene and nature returns to a peaceful state. At the same time, the camera stops spinning around the sorceress and is distanced from her. A long pause of silence (not indicated in the original text) defines this frame, which suddenly becomes a close-up when Prospera begins to meekly recite the renunciation of her magical powers ("But this rough magic I here abjure", almost dismissing with these terms what was previously seen as a "potent art"). Her glance seems for the first time to reveal insecurity, whilst she seems to be sadly saying goodbye to nature itself (and to the island).

The change in the atmosphere is reflected also in her tone of voice, which, contrary to the previous enraged and determined inflection, lowers until it is only a whisper. The flow of emotions expressed by the Academy Award-winner actress in this scene contains and almost summarizes the characterization of Prospera in the story at large, from her growing rage, firm determination and will to avenge herself to the calm which defines the finale of a work that Nemi d'Agostino has described, together with Pericles, Prince of Tyre, Winter's Tale and Cymbeline, as a "tragicomedy" or "romance" (xxviii) - a work that expresses a final message of detachment and peacefulness. In this sequence, the return of the sun and the tranquillity of nature expressly correspond with the calm of Prospera and the atmosphere of restored harmony, repentance and reconciliation.

Considering the performance-oriented nature of the original Shakespearean text, the intimate confession of the protagonist in this moment of solitude is by implication shared with the viewer in both its theatrical and cinematic versions. Taymor recreates such an intimacy through the use of a close-up. Indeed, when Prospera sanctions the promise to break her staff and to drown the books containing her spells, the camera gets close enough to frame only the sorceress' eyes. Although Mirren never looks at the camera to address us directly as viewers, we are invited to listen to Prospera's abjuring of her art through the slow approach of the camera. Indeed, as Ros Jennings has suggested, the close-up often "allow[s] us the privilege of glimpsing the 'private self'" (203) of a character and could thus reveal his/her deeper thoughts to the viewer.

This is confirmed by the fact that the frame changes as soon as Prospera interrupts her soliloquy-stream of thoughts when she realizes that Ariel is reaching her together with the three Neapolitans and Antonio. Such an atmosphere of intimacy with the protagonist's inner turmoil is further emphasized by the musical track "Rough Magic" which begins with a solemn and martial rhythm that apparently announces the beginning of a battle. Dissonance is then created by some chords which form a series of contrasts between the orchestral instruments and the electronic sounds. The dissonance produces an effect of continuous contrasts, of negative emotions that perfectly exemplify the contrasting feelings expressed by the protagonist's soliloquy in this scene.

Music is a constant presence in Shakespeare's The Tempest too, from the solemn or soft music produced by Ariel to charm and lure Prospero's adversaries and the spirit's own performance of "Full Fathom Five" (I, ii, 399-407) and "Where the Bee Sucks" (V, I, 88-94), to the many noises that fill the air of the isle according to Caliban (III, ii, 133) and the various sounds produced by nature, such as the thundering roaring of the storm and the sound of waves and wind. All of these constitute a frequent support to the characters' actions, as Agostino Lombardo has pointed out when arguing that in this work music has the function both of accompaniment and instrument of the action (xxxix). As is the case of the special effects enhancing and fully realizing on the screen the visual aspects of the written text, the auditive dimension of The Tempest, only imaginable by the readers of the play, can achieve its full realization in the cinematic medium - a particular which has been apparently ignored by Jarman, whose film, with the exception of the final celebration of the young couple's union through Elisabeth Welch's performance of "Stormy Weathers", has a minimal soundtrack and mainly reproduces the echoing footsteps of the characters in the mansion.

As Linda Hutcheon has evidenced, "soundtracks in movies enhance and direct audience response to characters and action" (41). In the case of a written song that has no accompanying authorial score, the musician has to carry out a series of procedures such as the interpretation and appropriation of the chosen text's contents and its transfer into an appropriate musical matrix as well as the creation of a new combination in which music and words coexist and reinforce each other simultaneously. For this specific task, Taymor has selected once again Elliot Goldenthal - composer of the soundtracks of Alien ${ }^{3}$, Interview with the Vampire and Batman Forever, to name merely a few of his works - with whom she had previously collaborated in the films Titus (1999) and Frida (2002). 
Goldenthal's music is generally modern in feel and very varied, alternating the violins defining the most melodic parts of the film (such as the "Brave New World" track accompanying the penultimate scene in which Miranda praises the beauty of mankind) to the electric guitars characterizing the more fast-paced scenes, as is the case of the cacophonous track "Lava Dogs", for example, which supports the scene near the end of the film in which the (computer-generated) dogs chase Caliban, Stefano and Trinculo out of Prospera's cell. We could then affirm that it is indeed an "isle full of noises" in the 2010 adaptation too, and these are the instruments of the orchestra, the "sounds and sweet airs that give delight and hurt not", to quote Caliban's words, and hum about the spectators' ears.

Particularly striking is Taymor's Caliban, interpreted by Djimon Hounsou. In the Shakespearean text, his characterization is figural (it occurs through other characters' comments) rather than authorial (through stage directions). Some of the terms and adjectives used by Prospero and Miranda to describe and address him are: "my slave", "a villain", "tortoise", a bastard "got by the devil himself", "poisonous", "lying", "abhorred" (I, ii, 310, 312, 319, 321, 346, 353). In the second act, his appearance provokes abjection in Trinculo, who immediately sees him as "a spectacular other" that could earn him some profit in England (Fuchs 48). After witnessing Caliban's worship of Stefano and of his bottle of wine, Trinculo describes him as "a very shallow monster ... A very weak monster! ... A most poor credulous monster!" (II, ii, 144-146). ${ }^{(3)}$ Caliban is frequently depicted with negative attributes: he is marginalized, abused and discriminated by means of a series of arguments that underline his physical difference as an undisputed sign of inferiority that is immediately visible and cannot be ignored by the other characters. He is also constantly threatened and becomes the victim of physical violence, which is inflicted almost sadistically by Prospera through magic.

Furthermore, as Lisa Hopkins has summarized, Caliban "can stand, albeit rather problematically, as an emblem of the colonized indigenous population" (Hopkins 12). ${ }^{(4)}$ Contemporary criticism has often debated that The Tempest mainly exemplifies the colonial transaction enacted in America after Columbus' arrival in 1492 and, to quote Silvio Torres-Saillant, Christian Europe's "imposition of its own knowledge and values upon the New World, leading to the dispossession, destitution and dehumanization of the indigenous and African-descended populations in the United States" (108-09).

This is firstly demonstrated by the fact that, as soon as he is introduced in the first act of the play, Caliban claims the right to govern over the island: "This island's mine, by Sycorax my mother, Which thou tak'st from me" (I, ii, 333-34) - a phrase that is particularly stressed by Hounsou's roaring pronunciation of it in Taymor's film. Caliban has been dispossessed of his "natural" and hereditary right over the land and has then been constructed as a colonial subject through a repertoire of positions of power and resistance, domination and dependence. According to this model Prospero assumes the role of white and male colonialist, who enslaves the native inhabitant of the island with his superior power (his magic) and forces him to perform the hard manual works. However, as was the case with the European colonists in America (Hulme 244), Prospero is simultaneously dependent on him for his knowledge of the local environment, his food supply and material requirements.

After the initial hospitality, however, Caliban denies his position as a slave and enacts a treacherous behaviour, which, as Peter Hulme argues (246-48), apparently justifies Prospero's need to further subject and abuse him. This has been evidenced in Stanislav Sokolov's Animated Tales version of the play (1992) and in Jarman's The Tempest. In the former, the stop-motion-animated puppet of Prospero beats the amphibian and deformed Caliban with his rod and repeatedly kicks him only because he comes too close to the sorcerer. Similarly, Jarman represents Prospero as willingly crushing with his foot the hand of the childish and almost idiotic slave (Jack Birkett) - who apparently compensates for Ariel's lack of joviality by laughing with no reason throughout many of the scenes in which he appears - simply because Caliban lingers behind a door when called by his master.

On the other hand, Caliban's perennial resentment and enraged frame of mind against his master are expressed through the irreverent language the character uses every time he addresses - or merely thinks of the magician. The 2010 film evidences his embodiment of hate by depicting him as very aggressive, assuming a threatening posture and using a loud voice when cursing against Prospera and Miranda, who are scared of him and very defensive - a particular underlined by the fact that the sorceress readily points her rod at him.

Most interestingly, the rebellious behaviour of the slave has been expressed by Taymor in visual terms by 


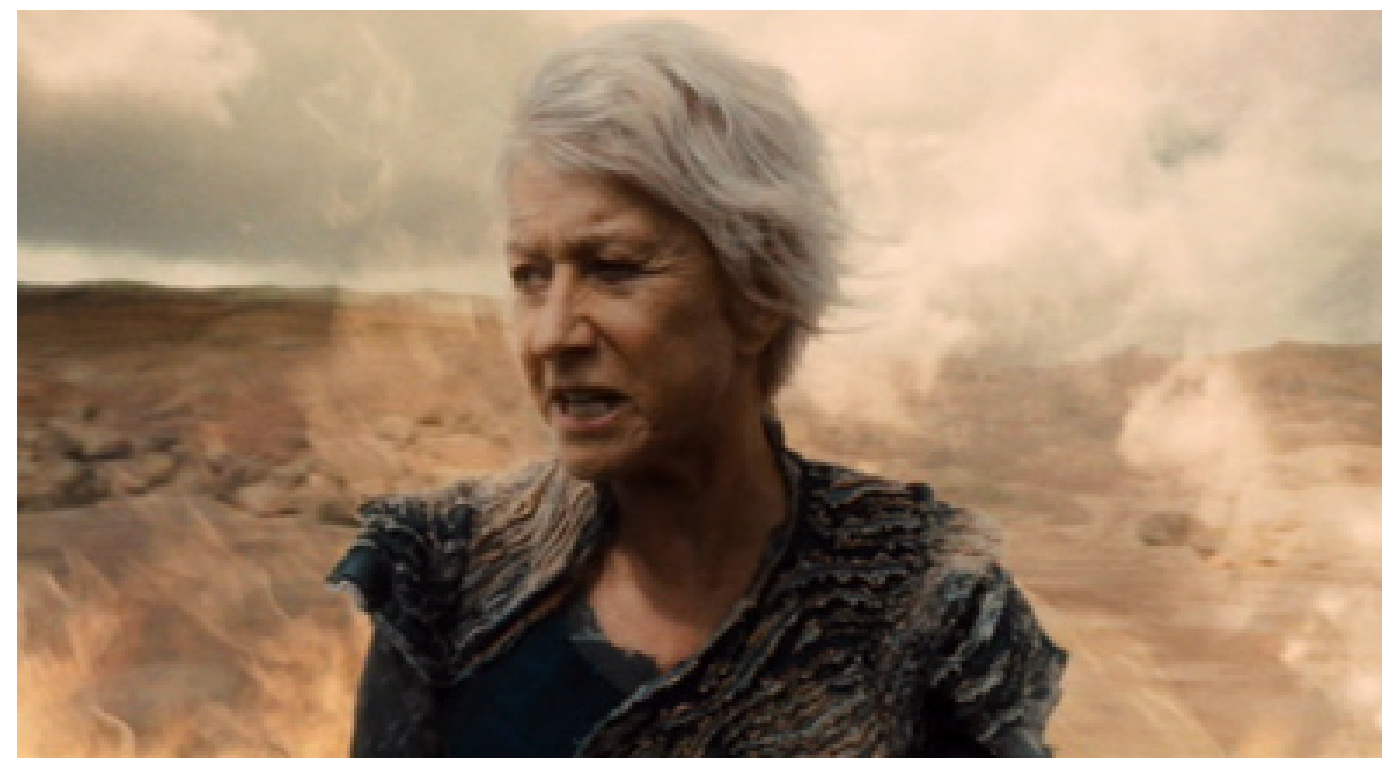

Figure 3: Image 3: Special effects transform Prospera's soliloquy into a realistic act of magic

means of the many Elizabethan curse words carved and scarred in the character's body. These are the insults Caliban reserves for Prospero and Miranda, who enslaved him and made him suffer for years: his body as much as his language express his anger and frustration. He thus literally embodies the phrase "You taught me language; and my profit on't Is, I know how to curse" (I, ii, 365-66). Hounsou underlines this by touching his body with both hands when pronouncing these verses, as if to actually point at the carved curses.

Nevertheless, in the previous cinematic productions, such as Percy Stow's The Tempest (1908), Jarman's The Tempest and Prospero's Books, this character has been cast as a white man. In these cases, he did not "offer anything that could resemble a postcolonial reading of the play" and "serve[d] to mark the extent of the divide between academic understandings of the play and the image of it presented on film" (Hopkins 101, 144). In the original text there are no explicit references to the character's race and skin colour and their relationship with the potential implication(s) for interpretation. The race, ethnicity and colour of the actor performing Caliban are nevertheless semiotically relevant in light of the academic debates surrounding such a character and, for this reason, do not always allow for colour-blind casting for the role (both in theatre and on the screen). Contrary to the previous cinematic versions of the play, Taymor's film reflects the influence of literary criticism by calling attention to race. Caliban is specifically signalled by his black skin tone, which thus alludes to a racist and prejudiced perspective that immediately identifies skin with a person's natural "identity". Clearly, this is not done to agree with Prospero's racist need to enslave him, but to depict the colonizing process as negative (although it could be argued that the well-meaning emphasis on the actor's muscular and almost naked body itself ultimately sends out racist signals).

On the one hand, Caliban is also an excellent instrument to indicate how much baser the corruption of the civilized can be than the bestiality of the natural, especially if we consider Antonio' and Sebastian's lack of scruples in attempting to kill Alonso and Gonzalo. On the other hand, Taymor's representation of Caliban encourages the viewer's sympathy for a character that is torn between his fear of the sorceress and the magical punishment she can inflict, and the passive willingness to accept his position as a slave, which he unquestionably demonstrates through the continuous submissive kneeling and the reverential whispering tone of voice he uses when addressing the butler Stephano.

Significantly, the lines from the original text that show Caliban's demand for Prospero's forgiveness and his intention to "be wise hereafter, And seek for grace" (V, I, 294-95) have not be included in the film's script, thus suggesting that he has no regrets for the betrayal of his authoritarian master. In this sense, his rebellious behaviour and attempt to free himself from the "colonial" domination of the powerful white woman seem to be justified in Taymor's film. This argument would be corroborated by the addition of Prospera's 
silent goodbye to her slave at the end of this scene. For the first time in the film, the sorceress' rod is not menacingly pointed at Caliban and her last glance towards him does not express anger or satisfaction for having foiled his murderous plan. Rather, she is sad to say goodbye to Caliban and seems to be experiencing a moment of revelation, in which she finally realizes the evil she has committed against him in the past and willingly gives him back the dominion over the island.

Taymor's film is certainly a great work of art. The only fault that could be ascribed to it is the fact that the substitution of the protagonist's sex could effectively "colonize" the imagination of the play's future readers, determining a difficulty with imagining a male wizard in Prospera's place, especially after watching Mirren's unforgettable performance. However, in spite of its alterations to the original text, this can be defined as a faithful rendering of Shakespeare's work.

Indeed, the formal features and major thematic concerns of the original theatrical text as well as the major actions of the plot and the characterization of the protagonists have not been altered. On the other hand, the 2010 version simultaneously epitomizes Linda Hutcheon's argument that "adaptation is repetition, but repetition without replication" (8), a repetition in which "the conservative comfort of familiarity is countered by the unpredictable pleasure in difference, for both creator and audience" (173). The various alterations we have examined never impoverish the primary sources; rather, the Shakespearean text is fully realized on the screen by means of the realistic special effects and the talent of the actors and actresses. Taymor's film shall therefore survive from the fury or disappointment of those Shakespearean fans and scholars who look at an adaptation of the Bard's work "as an intertext designed to be looked through, like a window on the source text" (Leitch 17), and find the alterations as "corrupting" or "perverting" the "sacred" form of the primary source.

The 2010 film certainly benefits from a comparison with the previous adaptation of the play by Jarman, whose realistic rendering of the story is a priori compromised by the dream format, suggested primarily by the fact that Prospero is represented as asleep at both the beginning and the end of the narrative and that the sorcerer's voice-over deep breathing prevails over the soundtrack on many occasions throughout the film. Furthermore, realism is "mauled" by the use of non-naturalistic colour effects inside the mansion, the use of blue filters for the scenes set on the exteriors, and also by the actors' overacting or their ineptitude to act. Similarly, in Greenaway's film realism is compromised by the fact that the story is continually interrupted by the protagonist's voice-over listing of his books and the explanation of their contents as well as by the recitation of all of the play's lines by Prospero up to the last part of the film (corresponding to the fifth act). A psychological interpretation of the story rather than a realistic development of it is therefore suggested by Greenaway.

A final note: it appears that the epilogue has been cut out. Instead of being recited by Prospera, the end titles reveal that it has been set to music by Goldenthal and sung by Beth Gibbons, singer of the English band Portishead. The text/lyrics, reminding the audience that the vision created by art finally must fade, are certainly appropriate for the end of the film as well, in which the image of the books sinking towards the sea floor visually shows the final renunciation of Prospera's magic. The titles roll to the end, the last book drowns, the passionate and melancholy song comes to a conclusion and the image fades to black.

Our revels now are ended.

\section{Notes}

1. The same combination of the theme of betrayal with a wooded scenery is reproduced in the following scene, in which Caliban, Stefano and Trinculo define their plan against Prospera's life inside an intricate forest.

2. The term "maze" is also utilized in reference to Ariel, who "flam'd amazement" (I, ii, 198) into the minds of the sailors during the tempest, and is then repeated when the spirit instils confusion into the minds of Alonso, Antonio and Sebastian, reducing them to a state of powerlessness and total insecurity.

3. Caliban could be characterized as a monstrous hybrid, because his black skin presents many white spots and some fossilized areas made of the very materials of the islands. As the film's director has affirmed 


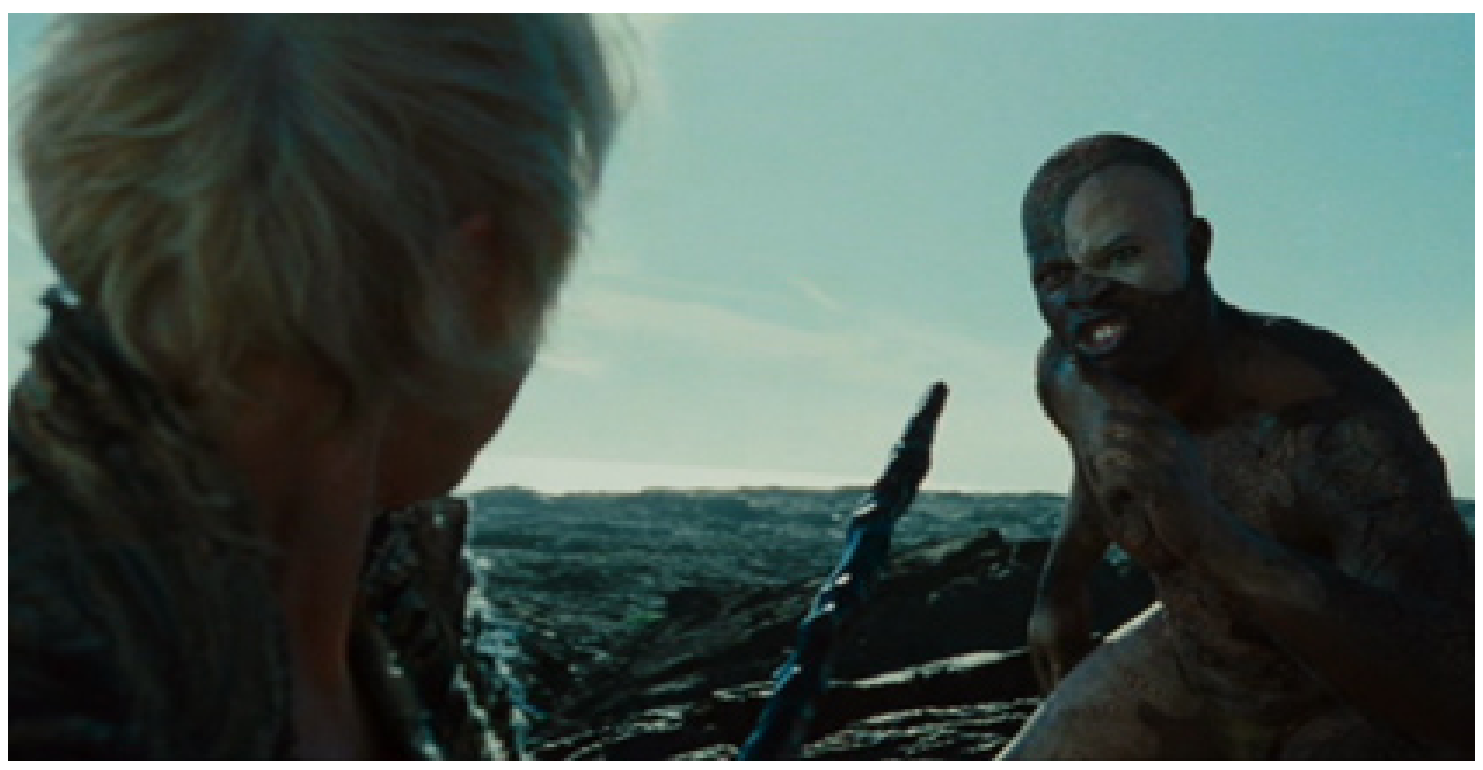

Figure 4: Image 4: An enraged Caliban addresses Prospera

in the DVD documentary "Raising The Tempest", in fact, "he has nature in him". This representation epitomizes his oneness with the nature of the island, a particular that in both the literary and the 2010 cinematic version is firstly suggested by Prospero/a calling him a thing of the earth: "Thou, earth, thou!" (I, ii, 316) and subsequently by Trinculo defining him "a natural" (III, ii, 31). In this way, Caliban exemplifies the contrast between civilization and nature, or, to be more precise, between educated Europeans and uneducated, "primitive" human beings living in closer contact with nature. According to Frank Kermode, indeed, in The Tempest Caliban's function is to illuminate by contrast the world of art, nurture, civility that Prospero mastered through (self-)discipline, temperance and secret studies (146)

4. He can even stand as an emblem of any indigenous population that has suffered from subjection by an external colonizer, as Barbara Fuchs affirms when arguing that there are strong analogies between Prospero's island and Elizabethan Ireland (45-46).

\section{References}

\section{Works Cited}

d'Agostino, Nenni. Prefazione. The Tempest. Milano, Garzanti, 1999. vii-xxxvi.

The Animated Tales: The Tempest. Dir. Stanislav Sokolov. BBC Wales, 1992.

Breznican, Anthony. "First Look: Helen Mirren in lead role in Julie Taymor's 'Tempest'." Accessed 04 Dec. 2013.

Boelhower, William. "Owning the Weather: Reading The Tempest After Hurricane Katrina." Borrowers and Lenders: The Journal of Shakespeare and Adaptation 5:2 (Fall/Winter 2010): 1-18. Accessed 30 Nov. 2013.

Fuchs, Barbara. "Conquering Islands: Contextualizing The Tempest." Shakespeare Quarterly 48 (1997). $45-62$.

Greenblatt, Stephen (ed.). The Norton Shakespeare: Based on the Oxford Edition. New York: W.W. Norton, 1997.

Hopkins, Lisa. Screen Adaptations: Shakespeare's The Tempest. The Relationship between Text and Film. Ed. Ian Hunter. London: Methuen, 2008. 
Hulme, Peter. "Prospero and Caliban." The Tempest. A Norton Critical Edition. Eds. Peter Hulme and William H. Sherman. New York: W.W. Norton, 2004. 233-49.

Hutcheon, Linda. A Theory of Adaptation. London: Routledge, 2006.

Jennings, Ros. "Desire and Design - Ripley Undressed." Immortal, Invisible: Lesbians and the Moving Image. Ed. Tamsin Wilton. London: Routledge, 1995. 193-206.

Kermode, Frank (ed.). Introduction. The Tempest. London: Methuen, 1971. xi-xciii.

Leitch, Thomas. Film Adaptation $\mathcal{E}$ its Discontents: From Gone with the Wind to The Passion of the Christ. Baltimore, MD: The Johns Hopkins UP, 2007.

Lombardo, Agostino. Prefazione. The Tempest. Milano, IT: Garzanti, 2012. xxxvii-l.

Nicora, Flaminia. "'This is as strange a maze as e'er man trod'. The Semiotics of Labyrinth in Shakespeare's The Tempest." Textus: English Studies in Italy 17:2 (2004). 275-89.

O'Toole, Michael. "Shakespeare's Natives: Ariel and Caliban in The Tempest." Accessed on 30 Nov. 2013.

Prospero's Books. Dir. Peter Greenaway. Sacha Vierny, 1991. Film.

Raising the Tempest. Dir. Julie Taymor. Touchstone Picture, 2010. Film.

Serpieri, Alessandro. Prefazione. Pericles, Prince of Tyre. $3^{\text {rd }}$ ed. Milano, Garzanti, 2008. xxxviii-li.

Shakespeare, William. Henry V. Milano, Mondadori, 1990.

. Pericles, Prince of Tyre. $3^{\text {rd }}$ ed. Milano, Garzanti, 2008.

. The Tempest. Milano, Garzanti, 2012.

The Tempest. Dir. Peter Stow. Clarendon Film Company, 1908.

The Tempest. Dir. Derek Jarman. Boyd's Company/Arthouse Films, 1979.

The Tempest. Dir. Julie Taymor. Touchstone Pictures and Miramax Films, 2010.

Torres-Saillant, Silvio. "1492 and the Ethics of Remembering." The Culture and Philosophy of Ridley Scott. Eds. Adam Barkman, Ashley Barkman and Nancy Kang. Lanham, MD: Lexington Books, 2013.

\section{Reports}

Photo credits: The Tempest (4 pictures) Touchstone Pictures and Miramax Films.

\section{Author Information}

Antonio SANNA received his $\mathrm{PhD}$ at the University of Westminster in London. His publications include articles on James's "The Turn of the Screw", Stoker's Dracula, H. G. Wells's The Island of Dr. Moreau, Victorian ghost stories and Beowulf; the Alien quadrilogy, Ridley Scott's Hannibal and the Harry Potter films. He has contributed to The Dictionary of Literary Characters. 